\title{
A study on relationship between social entrepreneurship and organizational commitment
}

\author{
Yadollah Hemmatia $^{a^{*}}$ and Seyed Hasan Kia ${ }^{\mathrm{b}}$
}

${ }^{a}$ Department of Management, Semnan branch, Islamic Azad university, Semnan, Iran

${ }^{b}$ Young researchers and elite club, Semnan branch, Islamic Azad university, Semnan, Iran

\section{H R O N I C L E}

Article history:

Received May 12, 2013

Received in revised format 30 June 2013

Accepted 28 July 2013

Available online

August 12013

Keywords:

Social entrepreneurship

Organizational commitment

Affective commitment

Normative commitment

\section{Introduction}

Today, the positive influence of entrepreneurship in the economy has been socially accepted. Entrepreneurs are able to provide efficient techniques to face with upcoming economic challenges and there are literally various studies on the effects of entrepreneurship on organizational performance (Landstrom, 2005). Derakhshandeh (2013), for instance, investigated the impact of entrepreneurship on growth of economy over the period 2005-2011. They also studied the effect of four factors including Gross domestic product per worker, Growth in capital per worker, New firm creation and Technological innovation intensity on economic growth. They reported that gross domestic product per worker was the only variable, which was statistically meaningful and the effect of other three variables including growth in capital per worker, new firm creation and technological innovation intensity were not statistically meaningful.

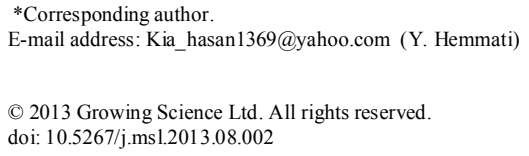


Intellectual capital is another important issue, which has significantly influenced organizational performance and identifying different methods to create, manage, and evaluate the effect of intellectual capital has become an open area of research. One of essential organizational capabilities, which help organizations create and share knowledge, is to implement knowledge to create competitive advantage. Darvish et al. (2013) investigated the impacts of intellectual capital on other components and their effects on organizational learning capability. They reported that human capital, relational capital and learning capabilities had positive impact on organizational performance. In addition, relational capital positively impacted learning capability and human capital influenced positively on relational capital. Azad and Majolan (2012) performed an empirical study on effects of knowledge management on organizational entrepreneurship. They reported that knowledge content was number one priority followed by knowledge tools and concept of knowledge (Lustri et al., 2007).

Abid et al. (2012) explored the authentic leadership styles of an entrepreneurs and its effects on employee's commitment and satisfaction. They reported that the opinion of employees' about authentic leadership could serve as the intoxicating analyst of employee job satisfaction and organizational commitment. Zakeri Nasrabadi et al. (2012) discussed three entrepreneurship opportunities including universities, technical and vocational centers and women. They explained that universities could educate highly skilled people and send them to business and they could create new ideas. Arab and Vakil Alroaia (2012) performed a comparative investigation of entrepreneurship in Iran and countries of Global Entrepreneurship Monitor. Vakil alroaia et al. (2012), in other work, used DEMATEL technique to categorize the entrepreneurial barriers in the industry of Iran in 2 groups of cause and effect. They also implemented fuzzy concept to handle any ambiguity on the feedbacks gathered from decision makers. They reported that two factors of "kind of management" and "organizational structure" were the most important factors. In addition, "legal obstacles" and "optimum use of financial resources" were at the highest degree of impression on business units.

\section{The proposed study}

In this study, we investigate the relationship between social entrepreneurship and organizational commitment among regular employees of Bank Mellat in city of Semnan, Iran. The proposed study considers the following three hypotheses,

1. There is a positive and significant relationship between affective commitment and employee social entrepreneurship.

2. There is a positive and meaningful relationship between employee engagement and social entrepreneurship.

3. There is a positive and meaningful relationship between normative commitment and social entrepreneurship.

Fig. 1 demonstrates the proposed study of this paper.

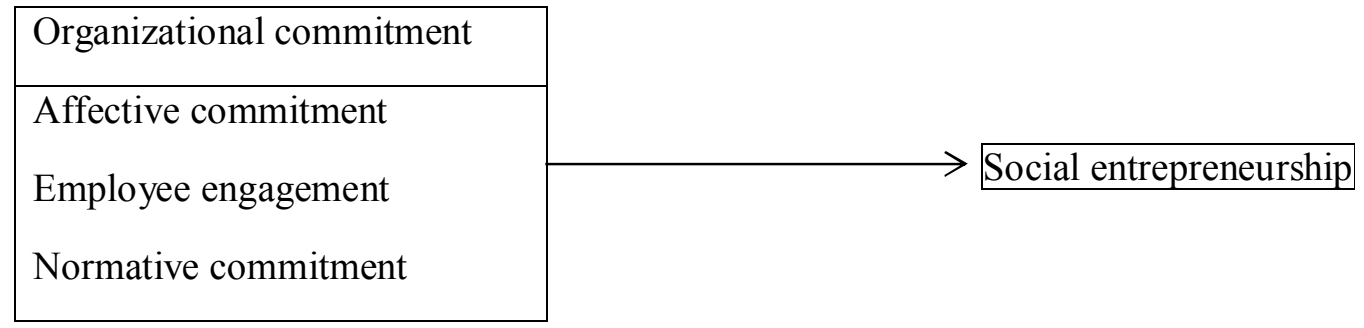

Fig. 1. The proposed study

The study has been performed among all employee of Bank Mellat located in city of Semnan, Iran. The study uses organizational commitment questionnaire developed by Meyer and Allen (1991). 
Cronbach alpha has been calculated for affective commitment, employee engagement and normative commitment as $0.77,0.79$ and 0.61 , respectively and these values are consistent with other studies.

\section{The results}

In this section, we present details of our finding on testing various hypotheses of this survey.

\subsection{The main hypothesis: Social entrepreneurship and organizational commitment}

The main hypothesis of this survey investigates the relationship between social entrepreneurship and organizational commitment. Table 1 demonstrates the results of our survey.

\section{Table 1}

The summary of testing the first hypothesis

\begin{tabular}{ccccc}
\hline Variable & Mean & Standard deviation & Pearson correlation & Sig. \\
\hline Social entrepreneurship & 3.33 & 1.079 & \multirow{2}{*}{0.78} & \multirow{2}{*}{0.000} \\
Organizational commitment & 2.65 & 1.061 & & \\
\hline
\end{tabular}

As we can observe from the results of Table 1, there is a strong and positive relationship between social entrepreneurship and organizational commitment when the level of significance is one percent. Therefore, the main hypothesis of the survey has been confirmed.

\subsubsection{The first hypothesis: Affective commitment and social entrepreneurship}

The first sub-hypothesis of this survey investigates the relationship between affective commitment and social entrepreneurship. Table 2 demonstrates the results of our survey.

\section{Table 2}

The summary of testing the first sub-hypothesis: affective commitment and social entrepreneurship

\begin{tabular}{lcccc}
\hline Attribute & Mean & Standard deviation & Correlation ratio & Sig. \\
\hline Affective commitment & 3.2 & 0.559 & 0.678 & 0 \\
\hline
\end{tabular}

As we can observe from the results of Table 2, there is a strong and positive relationship between social entrepreneurship and affective commitment when the level of significance is one percent. Therefore, the first sub-hypothesis of the survey has been confirmed.

\subsubsection{The second hypothesis: Employee engagement and social entrepreneurship}

The second sub-hypothesis of this survey investigates the relationship between employee engagement and social entrepreneurship. Table 3 demonstrates the results of our survey.

\section{Table 3}

The summary of testing the second sub-hypothesis: employee engagement and social entrepreneurship

\begin{tabular}{lcccc}
\hline Attribute & Mean & Standard deviation & Correlation ratio & Sig. \\
\hline Employee engagement & 2.97 & 0.780 & 0.386 & 0.0006 \\
\hline
\end{tabular}

The result of Table 3 also confirms that there is a strong and positive relationship between social entrepreneurship and employee engagement when the level of significance is one percent. Therefore, the second sub-hypothesis of the survey has been confirmed.

\subsubsection{The third hypothesis: Normative commitment and social entrepreneurship}

The third sub-hypothesis of this survey investigates the relationship between normative commitment and social entrepreneurship. Table 4 demonstrates the results of our survey. 
Table 4

The summary of testing the third sub-hypothesis: normative commitment and social entrepreneurship

\begin{tabular}{lcccc}
\hline Attribute & Mean & Standard deviation & Correlation ratio & Sig. \\
\hline Normative commitment & 3.49 & 1.095 & 0.752 & 0.0001 \\
\hline
\end{tabular}

Finally, the result of Table 4 confirms that there is a strong and positive relationship between normative commitment and employee engagement when the level of significance is one percent. Therefore, the third sub-hypothesis of the survey has been confirmed. We have also performed Freedman test to rank three components of the survey. Based on the results of Freedman test, normative commitment is number one priority with mean rank of 2.85 followed by affective commitment with mean rank of 2.47 and employee engagement with the mean rank of 2.26.

\section{Conclusion}

In this paper, we have presented a study to investigate the relationship between social entrepreneurship and organizational commitment among employees of Bank Mellat in city of Semnan, Iran. The study has adopted a standard questionnaire designed by Meyer and Allen (1991) and, through different questions in Likert scale, it has verified that all affective commitment, employee engagement and normative commitment have positively influenced organizational commitment, significantly. In addition, Freedman test has indicated that normative commitment is number one priority with mean rank of 2.85 followed by affective commitment with mean rank of 2.47 and employee engagement with the mean rank of 2.26 .

\section{References}

Abid, T., Altaf, M., Yousaf, U \& Bagram, M. (2012). Entrepreneur as an authentic leader: A study of small and medium sized enterprises in Pakistan. Management Science Letters, 2(7), 2355-2360.

Arab, Z., \& Vakil Alroaia, Y. (2012). A comparative investigation of entrepreneurship in Iran and countries of Global Entrepreneurship Monitor. Management Science Letters, 2(5), 1527-1534.

Azad, N \& Majolan, E. (2012). A study on effects of knowledge management on organizational entrepreneurship: A case study of educational system. Management Science Letters, 2(8), 27112716.

Darvish, H., Ahmadi, A., Kafashzadeh, A., Farid, S \& Nejatizadeh, N. (2013). Investigating the effects of intellectual capital on organizational performance measurement through organizational learning capabilities. Management Science Letters, 3(1), 165-172.

Derakhshandeh, A. (2013). A study on organizational entrepreneurship on economic growth. Management Science Letters, 3(1), 297-302.

Landstrom, H. (2005). Pioneers in Entrepreneurship and small Business Research methods: Historical Approach. Springer, Boston.

Lustri, D., Miura, I., \& Takahashi, S. (2007). Knowledge management model: practical application for competency development. The Learning Organization, 14(2), 186-202.

Meyer, J. P., \& Allen, N. J. (1991). A three-component conceptualization of organizational commitment. Human resource management review, 1(1), 61-89.

Meyer, J. P., Allen, N. J., \& Smith, C. A. (1993). Commitment to organizations and occupations: Extension and test of a three-component conceptualization. Journal of applied psychology, 78(4), 538.

Vakil alroaia, Y., Hemati, M., \& Javadinia, M. (2012). A new approach to develop entrepreneurship of the industry using fuzzy DEMATEL. Management Science Letters, 2(4), 1279-1288.

Zakeri Nasrabadi, Z., Nikbakht, A., \& Solimani Rad, A. (2012). A social work study on different entrepreneurship opportunities. Management Science Letters, 2(6), 2231-2236. 